\title{
Improving cervical cancer screening in Mexico: Results from the Morelos HPV Study
}

Yvonne Flores, PhD, (1) David Bishai, MD, PhD, (2) Eduardo Lazcano, MD, DrSc, ${ }^{(3)}$ Keerti Shah, MD, DrPH, (2) Attila Lörincz, PhD, (4) Mauricio Hernández, MD, DrSc, ${ }^{(3)}$ Jorge Salmerón, MD, D rSc, ${ }^{(1)}$

The Morelos HPV Study Collaborators.*(3,5,6,7,8)

\section{FloresY, Bishai D, Lazcano E, Shah K, Lörincz A, Hernández M, Salmerón J, The Morelos HPV Study Collaborators. Improving cervical cancer screening in Mexico: Results from the Morelos HPV Study. \\ Salud Publica Mex 2003;45 suppl 3:S388-S398. This paper is available too at: http://www.insp.mx/salud/index.html}

\begin{abstract}
A bstract
Objective. The purpose of this paper is to describe some of the results of the Morelos HPV Study. The main objective of the Morelos HPV Study is to evaluate the use of human papillomavirus (HPV) DNA testing, as compared to the Papanicolaou (Pap) test, for cervical cancer (CC) screening. Material and Methods. The Morelos HPV Study is currently being conducted in Mexico, to examine the possibility of using H PV testing for C C screening.The HPV testing of self-collected vaginal and clinician-collected cervical specimens was evaluated as part of this study. The acceptability of the HPV testing of self-collected specimens was compared to that of the Pap test. A cost-effectiveness analysis (CEA) and cost-benefit analysis (CBA) was also performed. Results. The Morelos HPV Study results indicate that HPV testing has a greater sensitivity to detect cervical intraepithelial neoplasia (CIN ) 2/3 and CC than the Pap test. 0 ur results also indicate an over-all lower acceptability of the Pap test as compared to the self-collected
\end{abstract}

\author{
FloresY, Bishai D, Lazcano E, Shah K, \\ Lörincz A, Hernández M, Salmerón J, \\ Grupo colaborador del Estudio Morelos deVPH. \\ Mejorando la detección oportuna del \\ cáncer cervical en México: resultados del \\ Estudio de VPH en Morelos \\ Salud Publica Mex 2003;45 supl 3:S388-S398. \\ Este artículo también está disponible en: \\ http://www.insp.mx/salud/index.html
}

\section{Resumen}

Objetivo. Describir algunos de los resultados del Estudio de VPH en Morelos. El objetivo principal del Estudio deVPH en Morelos es evaluar el uso de la prueba del virus de papiloma humano (VPH), en relación con la prueba de Papanicolaou, para el tamizaje de cáncer cervical. Material y métodos. El Estudio de VPH en Morelos actualmente se está llevando a cabo en México, para examinar la posibilidad de usar la prueba deVPH para la detección de cáncer cervical. Se evaluó el uso de la prueba deVPH en muestras auto-tomadas vaginales y en muestras cervicales tomadas por un clínico. Se comparó la aceptabilidad del uso de la prueba deVPH en muestras autotomadas al uso del Papanicolaou.También se realizó un análisis de costo-efectividad y de costo-beneficio. Resultados. Los resultados del Estudio deVPH en Morelos indican que la prueba de VPH tiene una mayor sensibilidad para detectar los casos de neoplasia intraepitelial cervical 2/3 y cáncer cervical que la prueba de Papanicolao u. Los resultados también indican una

* Daron Ferris, MD, ${ }^{(5)}$ Pilar Hernández, BA, ${ }^{(3)}$ Mark E Sherman, MD, ${ }^{(6)}$ Brigitte M Ronnett, MD, ${ }^{(6)}$ Enrique Carmona, MD, ${ }^{(7)}$ Alfredo Antúnez, MD, ${ }^{(7)}$ Horacio Manzanares, MD, ${ }^{(7)}$ Mario Uribe, MD, ${ }^{(7)}$ Ricardo Pérez-Cuevas, MD, MPH, ${ }^{(8)}$ A hideé Leyva, MSc, ${ }^{(3)}$ Elsa Yunes, MD, MSc. ${ }^{(3)}$

(1) Epidemiology and Health Services Research Department, The Mexican Institute for Social Security, Cuernavaca, Morelos, Mexico.

(2) The Johns Hopkins University, Bloomberg School of Public Health, Baltimore, MD, USA.

(3) Center for Population Health Research-N ational Institute of Public Health (IN SP), C uernavaca, Morelos, Mexico

(4) Digene Corporation, Gaithersburg, MD, USA.

(5) D epartment of Family Medicine, Medical College of Georgia, Atlanta, GA, USA.

(6) Department of Pathology and O bstetrics and Gynecology, The Johns Hopkins University, School of Medicine and Hospital, Baltimore, MD, USA

(7) Regional Hospital of the Mexican Institute for Social Security, Cuernavaca, Morelos, Mexico.

(8) Epidemiology and Health Services Research Department, The Mexican Institute for Social Security, Mexico, DF.

Received on: March 27,2003 - Accepted on: July 28, 2003

Address reprint requests to:Yvonne Flores. Unidad de Investigación Epidemiológica y en Servicios de Salud. Hospital General Regional con Medicina Familiar N o. 1.Avenida Plan de Ayala Esquina Central s/n, colonia Chapultepec, 62450 Cuernavaca, Morelos, México. e-mail: ivonne.flores@ imss.gob.mx 
procedure. The results of the CEA and CBA indicate that screening women between the ages of 20-80 for CC using some type of HPV testing is always more cost-effective than screening for $\mathrm{CC}$ using the Pap test. Conclusions. 0 ur results suggest that self- and clinician-collected HPV testing could be used in C C prevention programs, as an effective complement or substitute for the Pap test.This paper is available too at: http://www.insp.mx/salud/index.html

Key words: cervical cancer; screening; H PV testing; Pap aceptabilidad menor al uso de la prueba de Papanicolaou que al uso de la prueba de VPH auto-tomada. Los resultados del análisis de costo-efectividad y el análisis de costo-beneficio indican que el tamizaje con la prueba de VPH en mujeres de 20-80 años de edad siempre es más costo-efectivo que el tamizaje con el Papanicolaou. Conclusiones. N uestros resultados sugieren que la prueba delVPH (ya sea auto-tomada o clínica) podría ser utilizada en los programas de detección y prevención de cáncer cervical, como un complemento 0 un sustituto efectivo de la prueba de Papanicolaou. Este artículo también está dispo nible en:http://www.insp.mx/salud/index.html

Palabras clave: cáncer cervical; tamizaje; prueba delVPH ; Papanicolaou

\section{Burden of disease}

Cervical cancer $(\mathrm{CC})$ is a major public health problem in Mexico, and in many other developing countries. Over the past 25 years CC mortality rates have remained stable, fluctuating little from 16.9 per 100000 women in 1980 to 17.1 per 100000 in 1997. ${ }^{1}$ In 1992, Mexico had the highest CC mortality rate in the world, ${ }^{2}$ and it has ranked first in CC mortality for Latin America. ${ }^{3}$ Between 1980 and 1995 approximately 62000 women died from CC, and each year more than 4000 Mexican women die from this disease. ${ }^{4}$

The incidence of invasive CC in Mexico is also estimated to be one of the highest in the world. In 1985, the incidence of CC was estimated to be 40 new cases per 100000 women, and by 1997 this estimate had increased to 50 new cases per $100000{ }^{2,4}$ The mortality and high incidence rate of late stage CC are indirect evidence of the low impact of the Mexican National Cervical Cancer Screening Program (CCSP), especially since $90 \%$ of these cases can and should be detected using the Papanicolaou (Pap) test. ${ }^{5}$

Although there has been a national CCSP in effect since 1974, CC remains one of the leading causes of death for women in Mexico. ${ }^{6}$ It is the second most frequent cause of death for Mexican women, and it is the principal cause of death for women on reproductive age (15-49). ${ }^{7}$ Epidemiological reports from the Mexican Institute of Social Security (IMSS) indicate that in 1995, CC was the second most frequent cause of death due to cancer, and the leading cause of death due to cancer among women. ${ }^{8}$ In Mexico, the average age at death from CC is 48 , and $74 \%$ of these deaths occur between the ages of 30 and $64 .{ }^{9}$

\section{Problems with Pap Screening}

In Mexico, it has been difficult to establish and maintain an effective Pap-based screening program, such as those that are credited with reducing CC rates in the developed world. ${ }^{10}$ The CCSP has a very low coverage (approximately $20 \%$ annually, and $40 \%$ over a three year period); in 1996 an estimated 3516000 Pap tests were performed on a population of approximately 16507011 women between the ages of 25 and $65 .{ }^{11}$ Instead of being an early detection tool, the Pap test in Mexico is frequently used to diagnose advanced cases of CC. According to some studies, between 20 and $60 \%$ of all CC deaths could be prevented through an effective early detection CCSP. ${ }^{12}$ It has been reported that $60 \%$ of cases detected using the Pap test are invasive CC. ${ }^{12}$ The current CCSP prevents an estimated less than $13 \%$ of the potentially preventable cases of CC in Mexico. ${ }^{13}$

One of the explanations for the low coverage of the Mexican CCSP is the limited utilization and acceptability of the Pap test due to cultural and institutional barriers. ${ }^{14}$ Many women do not get a Pap test because they are uncomfortable with the pelvic examination, their male sexual partners will not let them, or because of a previous negative experience. Other reasons include: not knowing about the test, the perceived financial expense, and the long waiting time to get the test at a clinic and to receive the results. ${ }^{14}$

Although the efficacy of the Pap test has never been evaluated in a randomized trial, it is the primary tool for the screening of cervical neoplasia around the world. The decline in the number of advanced lesions and in the mortality rate for patients with CC that has occurred in the last 40 years has mainly been attributed to the introduction of this screening test. ${ }^{15}$ However, in the last two decades, this decreasing trend is no longer occurring in some developed areas, which have reported a significant increase in incidence and mortality among women under the age of 50 . This is probably related to an increase in the incidence of sexually transmitted diseases, including infection with certain types of human papillomavirus (HPV), ${ }^{16}$ which may have occurred $10-20$ 
years ago. Also important is the fact that in some developed countries with well screened populations, CC mortality rates have stabilized and large reductions in mortality are not expected. In a recent audit of the UK national CCSP, $50 \%$ of invasive cancers were detected in women who had been adequately screened. ${ }^{17}$ Recent attention has been focused on developing more sensitive and effective procedures that could be used to detect CC. One possible option is the use of HPV testing as an alternative to, or in conjunction with, the Pap test.

\section{HPV testing for cervical cancer screening}

Genital HPV infection is the most common sexually transmitted viral infection..$^{18}$ Infection with HPV through sexual contact has been determined to be a necessary risk factor for the development of CC..$^{19} \mathrm{~A}$ recent study reported that the worldwide HPV prevalence in cervical carcinomas is $99.7 \%{ }^{20}$ The presence of $\mathrm{HPV}$ in virtually all CC implies the highest attributable fraction that has been reported for a specific cause of any major human cancer, around the world. ${ }^{20}$ The official recognition of HPV infection as a necessary cause of cervical dysplasia and CC has produced an interest in the use of HPV diagnostic tests for screening activities. Some of the possible uses of HPV testing include: a) triage of women with low-grade Pap smear abnormalities, b) follow-up of women with confirmed cervical intraepithelial neoplasia (CIN), and c) primary screening. ${ }^{21}$ The use of HPV testing in CCSPs could have the following benefits, a) the sensitivity of CC screening results could be largely improved, b) women who are not infected with HPV could be screened at longer intervals, and c) limited resources for follow-up could be targeted better. ${ }^{22}$ Other benefits include the fact that the HPV test requires less technical resources, it is more reliable, less subjective, and relatively easier to perform than the Pap test. The higher costs that may be associated with HPV testing are likely to be offset by the savings in the direct and indirect costs of Pap testing and Colposcopy services, and by allowing longer screening intervals for HPV DNA negative women.

In direct comparison with the Pap, the HPV DNA test has a significantly greater sensitivity for premalignant lesions (CIN 2/3) ${ }^{23}$ Studies have also demonstrated that HPV testing can be used to triage females with inconclusive or low grade abnormalities on their Pap tests, with potential cost savings. ${ }^{24-26}$ Other studies indicate that a combination of HPV testing and repeated cytologic screening can provide a reasonably sensitive screening for CC, while limiting the use of overburdened colposcopy services. ${ }^{27-29}$ Finally, HPV testing may improve the sensitivity of CC screening services by identifying patients who harbor serious cervical lesions that are not detected by the Pap test, or who are at high risk for cervical neoplasia. ${ }^{30}$

On its own or in conjunction with cytology, there are a number of possibilities for incorporating HPV testing at different ages and at different screening intervals. Studies that have modeled different HPV screening strategies using various values for prevalence, sensitivity, and probability of progression indicate that it may be effective and cost-effective. ${ }^{22,31}$ However, current knowledge is incomplete and further studies and modeling are needed to evaluate the potential roles and most cost-effective use of HPV testing for screening purposes. ${ }^{32}$

\section{HPV prevalence}

It has been estimated that at least $50 \%$ of sexually active adults have had a genital HPV infection. ${ }^{33}$ Some studies suggest that the prevalence of HPV in men is similar to that found in women. ${ }^{34,35}$ When male partners of women with HPV-associated genital disease are examined by colposcopy and the acetic acid test, about 40 to $50 \%$ of them show HPV-associated lesions, and half of these lesions are sub-clinical. ${ }^{36}$ Another study reports that $32 \%$ of men with low-grade penile intraepithelial neoplasia were partners of women with CIN $2 / 3$, whereas $72 \%$ of men with high-grade penile intraepithelial neoplasia had female partners with CIN 2/3.36

The highest rates of HPV infection have consistently been found in sexually active women under the age of 25. This observation tends to be true even after adjusting for factors such as lifetime number of sexual partners. In some studies, older women appear to have a decreased prevalence of HPV due to biological effects, such as immunity, that may limit or clear the infection. ${ }^{33}$

Figure 1 shows the detection rates of HPV infection by collection type for the Morelos HPV Study. ${ }^{37}$ These findings indicate that the detection of HPV is greatest among younger women ( $\leq 25$ years of age), then it tends to drop until the age of 35 when it begins to increase again. This trend can be observed regardless of the HPV testing technique used. The U-shaped HPV prevalence results from the Morelos HPV Study indicate that, unlike other studies in the US and Europe which have reported that infection with HPV tends to decrease with age, prevalence of HPV increases among older women. This U-shaped curve is consistent with other studies of HPV prevalence in Latin America such as Costa Rica and Colombia that have found higher rates among younger and older women. ${ }^{38,39}$ The reasons for the variation in HPV prevalence rates by age and geographic region are not yet fully understood. Some explanations for this 


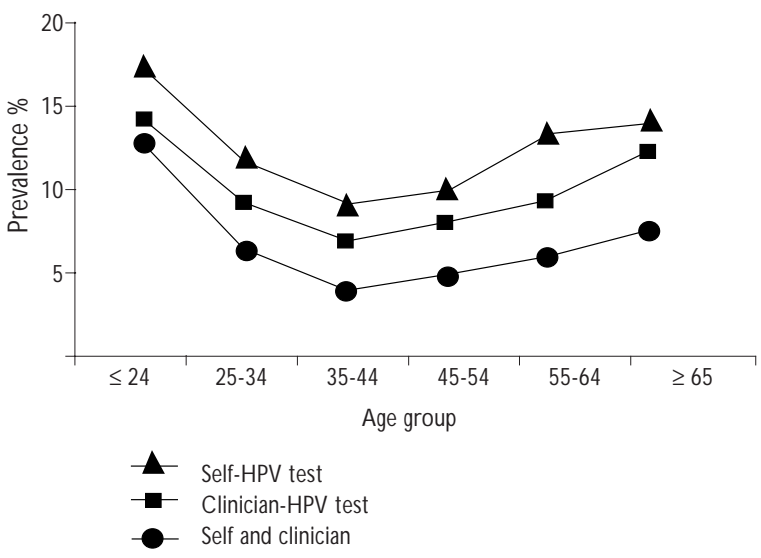

Source: D atabase Morelos H PV Project. Feb/2000

Figure 1. High-Risk HPV Detection Rates for the self AND CLINICIAN HC 2 TESTS.

phenomenon may include: a) a hormonal effect, b) a cohort effect, c) a reactivation of a latent infection, and d) an immune system response. Other reasons could be the HPV detection techniques that were used, or the type of study population that was selected.

These results also indicate that the HPV testing of self-collected specimens detects a larger number of women who are infected than does the testing of cliniciancollected specimens. However, since the HPV testing of self-collected specimens is less sensitive for detecting CIN $2 / 3$ and CC than the testing of clinician-collected specimens, these results indicate that the HPV testing of self-collected specimens detects more women infected with HPV that is not associated with CIN. A reason for this phenomenon could be that the vaginal self-collected specimens contain other types of HPV that are not found at cervical os, the area from which the clinician-collected specimens are obtained.

Figure 2 compares the age-specific prevalence of HPV detected in clinician-collected specimens, and the histologically confirmed cases of CIN 2/3 and CC found in the Morelos HPV Study population. These results indicate that the highest prevalence of HPV is found in the youngest and oldest age groups, which also report the lowest number of CIN 2/3 and CC cases. This information could have important implications in terms of the optimal age range for an HPV-based screening strategy.

The process by which an HPV infection progresses to carcinogenesis is not yet fully understood. The development of invasive cervical cancer has been regarded as a continuum that begins with mild dysplasia. Although low-grade lesions caused by HPV are usually transient, women with these lesions are at an increased

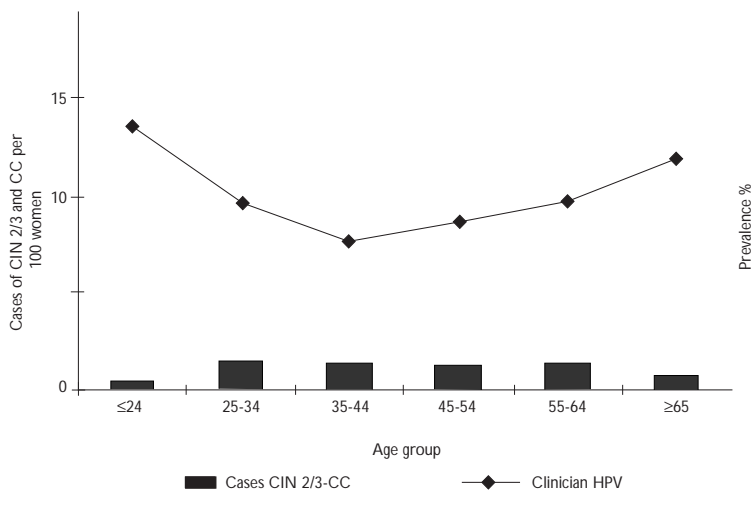

Figure 2. Rate of Cin 2/3 and cervical cancer DETECTED BY HISTOLOGIC DIAGNOSIS AND CLINICIAN-HPV prevalence rate by aGe Group in Morelos, 2000.

risk of developing higher-grade $\mathrm{CIN}$, the precursor to invasive carcinoma. High-grade CIN will usually occur in women with a previous low-grade diagnosis, but it can also emerge in women with a prior normal cytology or equivocal lesion diagnosis. The type of HPV found in the cervix appears to predict the risk of a woman progressing from a low-grade lesion to a diagnosis of CIN $2 / 3$. This association has been demonstrated in both crosssectional, ${ }^{40,41}$ and prospective, ${ }^{42,43}$ studies.

The incubation period for the development of a clinically apparent HPV infection (genital warts) varies from three weeks to eight months. However, most HPV infections in the squamous epithelium of the cervix remain at a sub-clinical level, providing a reservoir for the transmission of the virus. ${ }^{44} \mathrm{~A}$ latent infection may be converted to a replicative infection but the signal to initiate this process is not clear. Individuals who are physiologically (as in pregnancy), medically (as in taking steroids), or pathologically (as in HIV-infected) immunosuppressed, are at a significantly greater risk of replicative infections with HPV. When the individual is no longer in an immunosuppressed state the virus may again become latent, as is commonly observed postpartum, or a complete clearance of the infection may occur. ${ }^{45}$

Most HPV infections occur early in a person's sexual life, the overwhelming majority of infections are cleared by the host immune system, and persistent infection is strongly related to neoplasia. ${ }^{46}$ Recently results have been presented showing a median duration of HPV infection of only 8 months, and after 24 months, only $9 \%$ of the women studied continued to be infected. ${ }^{47}$ Although infection with HPV is quite common, relatively few infected women develop invasive cervical 
cancer. One study found that $12 \%$ of young women (13 to 22 years old) who were persistently HPV positive developed CIN 2/3 after two years. They also found that approximately $70 \%$ of the participants who were initially positive had HPV regression by 24 months. ${ }^{48}$ Another study found that $15.8 \%$ of patients with HPV progressed to CIN after 24 months, persistence occurred in $39.4 \%$ and regression in $44.8 \%$ of patients. ${ }^{49}$

Although infection with high-risk HPV types is a necessary factor for the development of CC, it is not sufficient, since the majority of infected women do not go on to develop this disease. CC usually develops after years or decades, apparently in association with other possible co-factors. Studies suggest that infection with high-risk types of HPV and older age are associated with persistence. Certain behaviors such as smoking, hormonal exposure (e.g. multiparity and prolonged use of oral contraceptives), nutritional deficiency, HLA haplotypes, other genital tract infections, and immunodeficiency (especially infection with HIV), are thought to be related to persistent infection and the development of CC. ${ }^{46,50,51}$

Women with persistent HPV infections, especially those with high-risk types, are at greater risk for developing CIN and CIN lesions that persist instead of regressing. The natural history of HPV infection directly influences the prognosis of cervical dysplasia as measured by persistence of the lesion. ${ }^{52}$ Studies indicate that persistence of high-risk HPVs may determine progression to more severe stages of the disease, and risk for disease progression also seems to be associated with viral burden. ${ }^{53,54}$

\section{The Morelos HPV Study}

\section{Study design and enrollment activities}

The Morelos HPV Study ${ }^{37}$ is currently being conducted in Mexico, to examine the use of HPV testing for cervical cancer screening. The main objective of the Morelos HPV Study is to evaluate the effectiveness of two different specimen collection strategies for HPV testing: selfcollected vaginal, and clinician-collected cervical, for detecting pre-invasive cervical lesions and CC, as compared to the Pap test. Another objective is to investigate the role of other factors, such as HPV viral load and types, for the risk of cervical intraepithelial neoplasia (CIN) $2 / 3$ and CC. An additional objective is to evaluate the cost-effectiveness of HPV testing, as compared to the Pap test.

This study is being carried out within the regular population-based framework of the IMSS CCSP in Morelos. The study participants were obtained as a sample of all consecutive women attending CC screening services at any one of the 23 health units that make up the CCSP in Morelos. Women attending any of the $\mathrm{CC}$ screening clinics in Morelos were invited to join the enrollment phase of the study between May and October 1999. Overall, the response rate to participate in the study was greater than $95 \%$. This study sample is considered representative of the women attending CC screening services at the 23 IMSS clinics in Morelos in 1999. All participants provided informed consent, after a written and oral explanation of the study was provided, at the recruitment visit.

Before the pelvic exam, participants were asked to provide a self-collected (SS) vaginal specimen for HPV testing. All participants also underwent a pelvic examination that involved collecting a cervical sample for the Pap smear, and a clinician-collected cervical specimen (CS) for HPV testing. The Digene Hybrid Capture (HC) 2 Probe B, microtiter assay was used to determine the presence of HPV. A specialized HPV lab was set up and validated at INSP with the help of Digene technicians, and the samples were tested according to the manufacturer's instructions. ${ }^{55}$

A total of 7872 women between the ages of 20 and 80, without a prior diagnosis of CIN $2 / 3$ or CC, hysterectomy or other treatment, enrolled in the study. Data were evaluated from 7732 women with complete information for the three tests (median age $=41$ ). The 1147 women who received at least one positive result (Pap, SS and/or CS) were asked to come back for a colposcopic evaluation. During colposcopy, biopsies were taken as appropriate, to histologically confirm a diagnosis of CIN $2 / 3$ or invasive cancer. A total of 1015 women returned for colposcopy; and 101 women received a histologically confirmed diagnosis of CIN 2/3 $(n=89)$ or CC $(n=12)$.

During the recruitment visit, all participants were interviewed by female staff using a standard IMSS registration form. In addition, during the initial recruitment visit a randomly selected subsample of 1069 participants were interviewed to collect additional information about their demographic data; obstetric, family planning and sexual history; risk factors for HPV and CC; knowledge and use of the CCSP; experience and acceptance of the Pap and HPV tests; patient costs of screening; and willingness to pay to reduce risk of CC.

\section{Results}

\section{HPV test performance results}

The oncogenic HPV detection rate observed among the Morelos HPV Study participants was found to be $11.6 \%$ for SS, and 9.3\% for CS. Fifty six Pap smear abnormalities 
were observed in $2.4 \%$ of the women. ${ }^{56}$ The relative sensitivity estimates for the Pap test, SS and CS were $59.4 \%(95 \% \mathrm{CI}, 49.2-68.9), 71.3 \%(95 \% \mathrm{CI}, 61.3-79.6)$, and 93.1\% (95\% CI, 85.8-96.9), respectively, while the specificities were $98.3 \%$ (95\% CI, 98.0-98.6), 89.2\% (95\% CI, 88.5-89.9), and $91.8 \%$ (95\% CI, 91.2-92.4), respectively. ${ }^{56}$ The positive predictive values of Pap, SS and CS were $36.1,9.1$ and 14.9 , the colposcopy referrals needed to detect a case of CIN2/3 or cancer were 2.8, 11.0 and 6.7 , respectively. ${ }^{56}$

Other recent studies have also reported that the HPV HC2 test has a greater sensitivity to detect CIN $2 / 3$ and CC than the Pap test. Table I summarizes the findings of some of these studies.

Preliminary results from other recent studies in Brazil, Canada, Germany and the United States, have also reported a greater sensitivity of HPV testing as compared to the Pap. ${ }^{67,68}$ These results suggest that selfand clinician-collected HPV testing could be used in CC prevention programs, as an effective complement or substitute for the Pap test.

\section{Acceptability results}

As previously mentioned, one of the reasons for the low coverage of the Mexican CCSP is the limited utilization and acceptability of the Pap due to socio-cultural factors. Some of these factors include: a) a reluctance to have a pelvic exam that may be embarrassing or painful; $b$ ) feelings of helplessness associated with the invasive nature of the exam; and c) the disapproval of a male partner. ${ }^{14}$

Recently, the acceptability of the Pap was examined in relation to the use of a self-sampling technique for HPV testing. ${ }^{69}$ This investigation was conducted as part of the Morelos HPV Study. A sub-sample of 1069 women was selected from the total Morelos HPV Study population of 7732. These women were asked to provide a self-collected vaginal specimen, to undergo a pelvic exam that included a Pap test, and to answer an in depth questionnaire. The acceptability component of the questionnaire addressed the perception of the level of pain, discomfort, embarrassment, and privacy experienced with the Pap and self-sampling procedures. Respondents were asked to rate their answers using a Likert scale, where a score of "1" represents low acceptability and a score of "5" indicates a high acceptability.

Figure 3 compares the respondents' experience with both the Pap and self-sampling procedures in terms of over-all acceptability, pain, embarrassment, discomfort, and privacy. The respondents showed a strong preference for the self-sampling technique as compared to the Pap test, as measured by the Likert scale, $(68 \%$ vs. $32 \%){ }^{69}$ The respondents also indicated a greater amount of pain, embarrassment, and discomfort associated with the Pap test, as compared to the self-sampling procedure. More women reported increased privacy associated with the self-sampling technique than with the Pap test. Most of the women $(93.1 \%)$ who reported that they preferred the Pap test indicated that they had more confidence in the procedure. ${ }^{69}$

It is important to note that these women were asked to rate their acceptance of the Pap and selfsampling procedures without knowing the sensitivity and specificity of these screening techniques. Had these women been informed of the fact that the sensitivity of the Pap is actually lower than that of the HPV test on self-sampled specimens, the acceptability of the Pap may have been even lower.

\section{Cost-effectiveness}

There are few studies that have examined the costeffectiveness of HPV testing as compared to the Pap. A recent review of 2100 papers that address the role of HPV testing for CC screening found that the existing modeling studies are inadequate for assessing cost-effectiveness. ${ }^{70}$ This report was disseminated in 1999, at a time when there were far fewer published studies on the effectiveness of HPV testing. Since 1999, a number of studies have published very promising results on the high sensitivity and potential applications of HPV testing.

Some studies that have examined the costeffectiveness of HPV testing, such as van Ballegooijen

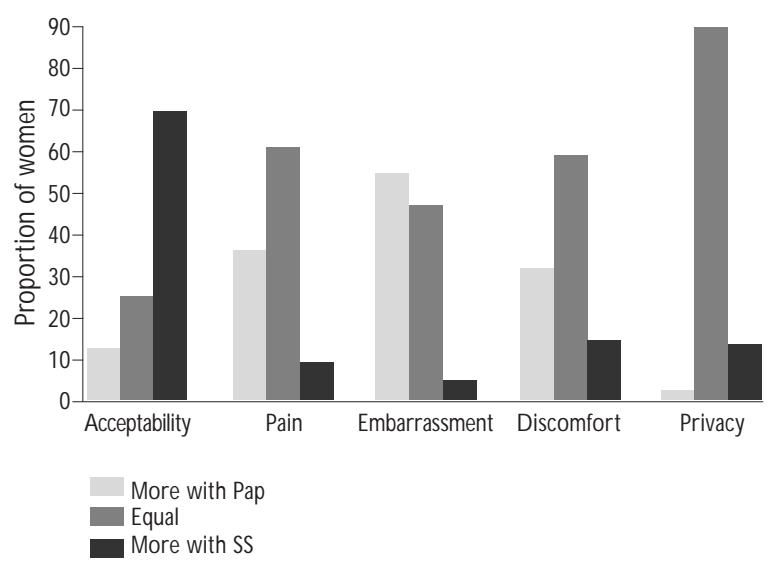

* From reference 69

Figure 3. Comparison OF WOMEn'S EXPerience With the Pap test vs. A self-sampling procedure* 
TABLE I.

SENSITIVITY AND SPECIFICITY OF THE SELF- AND CLINICIAN-COLLECTED HPV HC 2 TeSTS

\begin{tabular}{|c|c|c|c|c|c|c|c|c|c|}
\hline \multirow[b]{2}{*}{ Reference } & \multirow{2}{*}{$\begin{array}{l}\text { Location } \\
\text { and period }\end{array}$} & \multirow{2}{*}{$\begin{array}{l}\text { Age range } \\
\text { (mean) }\end{array}$} & \multirow[b]{2}{*}{ N } & \multicolumn{2}{|c|}{ Self } & \multicolumn{2}{|c|}{ Clinician } & \multirow[b]{2}{*}{ To detect } & \multirow{2}{*}{$\begin{array}{l}\text { Reference } \\
\text { population }\end{array}$} \\
\hline & & & & Sens & Spec & Sens & Spec & & \\
\hline $\begin{array}{l}\text { Morelos HPV } \\
\text { Study } 2000^{56}\end{array}$ & $\begin{array}{c}\text { Mexico } \\
1999 \\
\end{array}$ & $\begin{array}{l}20-80 \\
(42.5) \\
\end{array}$ & 7736 & 71.3 & 90.4 & 93.1 & 92.8 & CIN 2/3+ & Routine Pap \\
\hline $\begin{array}{l}\text { Schiffman M } \\
\text { et al. } 2000^{57}\end{array}$ & $\begin{array}{l}\text { Costa Rica } \\
\text { 1993-1995 }\end{array}$ & $\begin{array}{c}\text { 18-90t } \\
\text { (37 med.) }\end{array}$ & 1119 & -- & -- & 88.4 & 89.0 & $\operatorname{CIN} 2 / 3+$ & Routine Pap \\
\hline $\begin{array}{l}\text { Womack S } \\
\text { et al. } 2000^{58}\end{array}$ & $\begin{array}{c}\text { Zimbabwe } \\
1999\end{array}$ & $\begin{array}{c}25-55 \\
--\end{array}$ & 2140 & -- & -- & 83.9 & 57.8 & CIN 2/3+ & Routine Pap \\
\hline $\begin{array}{l}\text { W right TC } \\
\text { et al. } 2000^{59}\end{array}$ & $\begin{array}{c}\text { So. Africa } \\
\text { 1998-1999 }\end{array}$ & $\begin{array}{c}35-65 \\
-- \\
\end{array}$ & 1415 & 66.1 & 82.9 & 83.9 & 84.5 & CIN 2/3+ & $\begin{array}{l}\text { Previously } \\
\text { unscreened }\end{array}$ \\
\hline $\begin{array}{l}\text { Lin CT et al. } \\
2000^{60}\end{array}$ & Taiwan & $\begin{array}{c}50-78 \\
(62 \text { med.) }\end{array}$ & 119 & & & 100 & 64.8 & CIN 2+ & $\begin{array}{c}\text { Colpo } \\
\text { (Abn. Pap) }\end{array}$ \\
\hline $\begin{array}{l}\text { Sellors JW } \\
\text { et al. } 2000^{61}\end{array}$ & $\begin{array}{c}\text { O ntario } \\
1996-1997\end{array}$ & $\begin{array}{c}18+ \\
(31.5)\end{array}$ & 596 & 86.2 & 53.5 & 98.3 & 52.1 & CIN 2/3+ & $\begin{array}{c}\text { Colpo } \\
\text { (Abn. Pap) }\end{array}$ \\
\hline $\begin{array}{c}\text { Fait G et al. } \\
2000^{62}\end{array}$ & $\begin{array}{c}\text { Tel Aviv } \\
\text { 1996-1997 }\end{array}$ & $\begin{array}{l}17-48 \\
(28.2) \\
\end{array}$ & 503 & -- & -- & 88.2 & 94.7 & $\begin{array}{l}\text { CIN } 2 \\
\text { CIN } 3\end{array}$ & $\begin{array}{c}\text { Colpo } \\
\text { (ASC-US, LSIL) }\end{array}$ \\
\hline $\begin{array}{l}\text { Bergeron C } \\
\text { et al. } 2000^{63}\end{array}$ & $\begin{array}{c}\text { Paris } \\
1996-1998 \\
\end{array}$ & $\begin{array}{c}15-75 \\
(35)\end{array}$ & 378 & -- & -- & 88.0 & 49.0 & CIN 2/3+ & $\begin{array}{c}\text { (ASC-US, LSIL) } \\
\text { Colpo }\end{array}$ \\
\hline $\begin{array}{c}\text { Clavel C et al. } \\
\quad 1999^{64}\end{array}$ & $\begin{array}{c}\text { France } \\
1997-1998\end{array}$ & $\begin{array}{c}15-72 \\
(37)\end{array}$ & 1518 & -- & -- & 100 & 85.2 & CIN 2/3+ & $\begin{array}{l}\text { Routine } \\
\text { Pap }\end{array}$ \\
\hline $\begin{array}{c}\text { Cuzick J et al. } \\
\quad 1999^{65}\end{array}$ & England & $\begin{array}{l}34+ \\
(46)\end{array}$ & 1703 & -- & -- & 95.2 & 95.9 & CIN 2/3+ & Routine Pap \\
\hline $\begin{array}{c}\text { Ferris et al. } \\
1998^{66}\end{array}$ & USA & $18+$ & 242 & -- & -- & 90.5 & 29.4 & $\operatorname{CIN} 2 / 3+$ & $\begin{array}{c}\text { Colpo } \\
\text { (ASC-US, LSIL) }\end{array}$ \\
\hline
\end{tabular}

et $a l_{,}^{71}$ are limited by the estimates of the effectiveness of HPV testing they used. More accurate estimates of the effectiveness of HPV testing are only currently becoming available. These studies are also limited by the estimates of the cost of the HPV test they used because it is not known what the cost of the test will be for high-volume screening. The results of modeling studies indicate that for plausible values of prevalence, sensitivity, and disease progression, the use of HPV testing could be cost-effective. ${ }^{70}$ However, since these modeling studies have used imprecise input parameters due to lack of data, additional studies are required to improve the estimates of the key model parameters needed to perform an accurate and up-to-date costeffectiveness analysis (CEA).

In order to determine what CC screening strategy is the most appropriate, it is important to compare the benefits and costs of each strategy. A recent study by Mandelblatt et al..$^{22}$ used a mathematical model of the natural history of $\mathrm{CC}$ to estimate the benefits and costs of screening the average US population. The use of HPV testing alone and in combination with the Pap test was compared to screening with the Pap test on its own. This study used published estimates of costs and effectiveness to create their model. The study concluded that screening with both the Pap and HPV test every two years results in additional years of life saved at a reasonable cost, compared to Pap testing alone.

Another recent study by Goldie et al. ${ }^{31}$ examined the policy implications of several CC screening strategies in low-resource settings. A CEA was performed using a mathematical model and a hypothetical cohort of 30 year-old, black, South African women who had never been screened for CC. The performance of various screening tests including, direct visual inspection of the cervix, cytology, and HPV testing, were evaluated. The researchers who conducted this study used data from a South African screening study, a national survey, fee schedules, and published literature, to create their model. The study reports that when all strategies are 
compared simultaneously, HPV testing every three years is the most cost-effective option.

These two studies provide important information about the cost-effectiveness of HPV testing for CC screening. However, the results of these studies are based on cost and effectiveness parameters that were estimated using previously published data from many different sources. An economic evaluation of HPV testing that is based on cost and effectiveness data obtained from an actual CCSP context is also needed in order to further assess the role of HPV testing for CC screening. These data were obtained as part of the Morelos HPV Study.

A CEA and a cost-benefit analysis (CBA) were performed using data from the Morelos HPV Study, to further evaluate the possibility of using HPV testing as a screening technique for the detection of CC. The costs and benefits of the following interventions were evaluated and compared: a) using only the Pap test vs. self- or clinician-HPV testing for CC screening; $b$ ) using the clinician-HPV test in conjunction with the Pap test, and c) using different screening options for different age groups. The CEA and CBA were performed from the perspective of society and IMSS. The results of the CEA and CBA indicate that screening women between the ages of 20-80 for CC using some type of HPV testing is always more cost-effective than screening for $\mathrm{CC}$ using the Pap test. ${ }^{72}$ The cost-effectiveness results vary based on the cost that is assigned to missed cases of CC. If a cost of $\$ 500$ per missed case is used, the most costeffective option is Self-HPV testing followed by Pap testing, Clinician-HPV testing, then Pap in conjunction with Clinician-HPV testing, respectively. If a cost per missed case of $\$ 10,000$ is used, the most cost-effective option is Pap in conjunction with Clinician-HPV testing, followed by Clinician-HPV testing Self-HPV testing, then Pap testing respectively. These results will be reported in a future publication.

\section{Discussion}

Until recently, most studies have focused on the use of the clinician-collected HPV test, rather than the selfcollected test. Also, previous studies have not examined the potential use of different test combinations. Of particular importance are the reference populations that have been used for these studies; most have focused on the use of HPV testing in women who are attending colposcopy. The sensitivity and specificity results in studies using a colposcopy population will be different than those of studies that use a routine Pap screening population. The HPV test may have a greater sensitivity and a lower specificity to detect CIN 2/3 and $C C$ when it is applied to a colposcopy population, than when it is used within a regular screening population. This is because women who are referred to colposcopy have evidence of a cervical lesion, but most will not have high grade cervical disease.

Also, very few studies have been conducted within an actual population-based CCSP. Evaluating the use of HPV testing for primary screening is very relevant, and this must be done using a population of women who are attending routine Pap screening services. Studies that take place within an established CCSP can produce results that will be applicable for the specific screening program context. Finally, because the specificity of the HPV tests is relatively low, identifying strategies that could be used to improve it is a priority. Since many women who test positive for HPV will never go on to develop high grade CIN and cancer, it is important to find ways to distinguish the HPV positive women who are at greater risk of high grade disease, from those who may not be at risk.

The results from the Morelos HPV Study indicate an over-all lower acceptability of the Pap test as compared to the self-sampling procedure. This finding has important implications concerning the potential use of self-sampling CC screening services for women who reject Pap-based screening programs. However, it is also important to note that most of the study participants indicated no difference in pain, discomfort, or privacy between the Pap test and the self-sampling procedure. This finding is significant because it implies that a large number of women appear to accept the pelvic examination that is required to perform a Pap test. As noted previously, the Morelos HPV Study results indicate that the HPV testing of cliniciancollected cervical specimens has a higher sensitivity for detecting CIN 2/3 and CC when compared with HPV testing of vaginal self-collected specimens (93\% vs. $71 \%$, respectively). ${ }^{56}$ This finding suggests that the HPV testing of clinician-collected specimens could potentially be a more effective CC screening option. The fact that a significant number of women would agree to have a pelvic exam is a necessary first step to implementing HPV testing of clinician-collected cervical specimens as a viable CC screening option.

The baseline results of the Morelos HPV Study indicate that the use of Pap testing on its own is not as effective as the use of HPV testing to screen for CC. The combined use of the Pap and the clinician-collected HPV test appears to be the most effective and costeffective option to detect cases of CIN 2/3 and cervical cancer. Although the self-collected HPV test was not found to be as effective or cost-effective as the Pap- 
HPV test combination, the acceptability results indicate that most study participants showed a strong preference for the self-sampling technique. These findings suggest that the self-collected HPV test could be an attractive option for women who refuse to get a Pap or clinician-collected HPV test because of the pelvic examination. The self-HPV test could be used as an alternative way to reach these women, and increase the coverage of CC screening programs.

Future studies need to examine the costeffectiveness and cost-benefit of HPV testing as part of a long-term population-based screening program. Two such demonstration studies are currently underway in the states of Morelos and Tlaxcala in Mexico. These longterm studies will provide valuable information about the ideal screening intervals for HPV testing, as well as long-term cost-effectiveness results. One of the benefits of HPV testing is the fact that women who are negative may not need to be screened as frequently, which could result in additional cost savings. Future research should also examine the potential social consequences that women may experience from receiving an HPV positive diagnosis. A screening program that is based on HPV testing may have to take into account issues associated with screening for a sexually transmitted infection, as well as those associated with screening for CIN and CC.

\section{References}

1. Secretaría de Salud. Estadísticas de mortalidad relacionada con la salud reproductiva. México, 1997. (Indicadores). Salud Publica Mex 1999:41:138-46.

2. Lazcano-Ponce EC, N ájera-A guilar P, Buiatti E,Alonso-de Ruiz P, Kuri $P, C$ antoral $L$, et al.The cervical cancer screening program in Mexico: Problems with access and coverage. $\mathrm{C}$ ancer $\mathrm{C}$ auses $\mathrm{C}$ ontrol 1997;8:698-704.

3. Dirección General de Estadística I y E. Estadísticas sobre tumores malignos en México. Dirección General de Estadística, Informática y Evolución. Salud Publica Mex 1997;39:388-399.

4. Hernández-Avila M, Lazcano-Ponce EC,Alonso-de Ruiz P, Romieu I. Evaluation of the cervical cancer screening program in Mexico: A population-based case-control study. Int J Epidemiol 1998;27:1-7. 5. N ational Cancer Institute W orkshop:The 1988 Bethesda System for reporting cervical/vaginal cytological diagnoses. JAMA. 1989;262:931-934. 6. Lazcano-Ponce EC, Rascón-Pacheco RA, Lozano-Ascencio R,VelascoMondragón HE. Mortality from cervical carcinoma in Mexico: Impact of screening, 1980-1990. Acta Cytol 1996;40:506-512.

7. Secretaría de Salud. La Perspectiva de Género en la Salud. 1996. 8. Salmerón-C astro J, Franco-Marina F, Salazar-Martínez E, LazcanoPonce EC. Panorama epidemiológico de la mortalidad por cáncer en el IMSS: 1990-1995. Salud Publica Mex 1997;39:266-273.

9. Compendio del Registro Histopatológico de $\mathrm{N}$ eoplasias en México. Morbididad y Mortalidad Secretaría de Salud. 1a Edición. 1996:35-37.
10. Lazcano-Ponce EC, Moss S,Alonso-de Ruiz P, Salmerón-Castro J, Hernández-Avila M. Cervical cancer screening in developing countries:W hy is it ineffective? The case of Mexico.Arch Med Res. 1999;30:240-250. 11. Lazcano-Ponce EC, Buiatti E, N ájera-A guilar P,Alonso-de Ruiz P, Hernández-Avila M. Evaluation model of the Mexican national program for early cervical cancer detection and proposals for a new approach. Cancer Causes Control 1998;9:1-11.

12. Hernández-Avila M, Lazcano-Ponce EC,Alonso-de Ruiz P, LópezCarrillo L, Rojas-Martínez. Evaluación del programa de detección oportuna del cáncer del cuello uterino en la Ciudad de México:Un estudio epidemiológico de casos y controles con base poblacional. $\mathrm{Gac}$ Med Mex 1994;130:201-209.

13. Lazcano-Ponce EC, N ájera-A guilar P, Alonso-de Ruiz P, Buiatti E, Hernández-A vila M. Programa de detección oportuna de cáncer cervical en México: Diagnóstico situacional. C ancerología 1996;42:123-140. 14. Lazcano-Ponce EC, Castro R,Allen B, N ájera-A guilar P,Alonso-de Ruiz P, Hernández-Avila M. Barriers to early detection of cervicaluterine cancer in Mexico. JW omens Health 1999; 8(3):399-408. 15. Mitchell MF,Tortolero-Luna G,W right T, Sarkar A, Richards-Kortum $\mathrm{R}$, Hong W $\mathrm{K}$ et al. Cervical human papillomavirus infection and intraepithelial neoplasia:A review. J N atl C ancer Inst Monogr 1996;(21):17-25. Review.

16. Herrero R. Epidemiology of cervical cancer. Monogr N atl Cancer Inst 1996;21:1-6.

17. C uzick J, Meijer CJ,W alboomers JM. Screening for cervical cancer. Lancet 1998;351:1439-1440.

18. Division of STD Prevention. Prevention of Genital HPV Infection and Sequelae: Report of an External C onsultants' Meeting. Department of Health and Human Services,Atlanta: Centers for Disease Control and Prevention (CDC), D ecember 1999 .

19. Schiffman MH, Bauer HM, Hoover RN, Glass AG, Cadell DM, Rush $B B$, et al. Epidemiologic evidence showing that human papillomavirus infection causes most cervical intraepithelial neoplasia.J $\mathrm{N}$ atl $\mathrm{C}$ ancer Inst 1993:85:958-964.

20.W alboomers JM, Jacobs MV, Manos MM, Bosch FX, Kummer JA, Shah $\mathrm{KV}$ et al. Human papillomavirus is a necessary cause of invasive cancer worldwide.J Pathol 1999;189:12-19.

21. Cuzick J, Human Papillomavirus testing for primary cervical cancer screening. JAMA. 2000;283:108-109.

22. Mandelblatt JS, Law rence W F,W omack SM, Jacobson D,Yi B, H wang $Y T$ et al. Benefits and costs of using HPV testing to screen for cervical cancer. JAMA 2002;287(18):2372-2381.

23. Lörincz AT, Richart RM. Human papillomavirus DN A testing as an adjunct to cytology in cervical screening programs. Arch Pathol Lab Med 2003;127(8):959-968.

24. Ferenczy A.Viral testing for genital human papillomavirus infections: Recent progress and clinical potentials. Int J Gynecol C ancer 1995;5:321-328.

25. Richart RM. Screening:The next century. C ancer 1995;15;76(10 suppl):1919-1927.

26. Hatch KD, Schneider A, A bdel-N our MW. An evaluation of human papillomavirus testing for intermediate- and high-risk types as triage before coloposcopy. Am J O bstet Gynecol 1995;172:1150-1157.

27. C ox JT, Schiffman MH,W inzelberg AJ, Patterson JM. An evaluation of human papillomavirus testing as part of referral to colposcopy clinics. O bstet Gynecol 1992;80:384-389.

28. Lörincz,AT. Hybrid capture method for detection of human papilloma virus DNA in clinical specimens. Papillomavirus Report 1996;7:1-5.

29. W right TC, W ei Sun $X$, Koulos J. Comparison of management algorithms for the evaluation of women with low-grade cytologic abnormalities. 0 bstet Gynecol 1995;85:202-210. 
30. Serwadda D, W awer MJ, Shah KV, Sewankambo N K, Daniel R, Li C et al. Use of a hybrid capture assay of self-collected vaginal swabs in rural U ganda for detection of human papillomavirus.J Infect $D$ is 1999;180:316-319

31. Goldie SJ, Kuhn L, D enny L, Pollack A, W right TC. Policy analysis of cervical cancer screening strategies in low-resource settings: clinical benefits and cost-effectiveness. JAMA. 2001;285(24):3107-3115. 32. C uzick J, Sasieni P, D avies P,A dams J, N ormand C, Frater A et al. A systematic review of the role of human papillomavirus (HPV) testing within a cervical screening programme: summary and conclusions. Br J Cancer 2000;83:561-565.

33. Koutsky L. Epidemiology of genital human papillomavirus infection. Am J Med 1997;102:3-8.

34. Hippeläinen $M$, Syrjänen S, Hippeläinen $M$ et al. Prevalence and risk factors of genital papillomavirus infections in healthy males: A study on Finnish conscripts. Sex Transm D is 1993;20:321-328.

35. Grussendorf-C onen El, de Villiers EM, G issmann L. Human papillomavirus genomes in penile smears of healthy men. (Letter) Lancet 1986; ii:1092.

36. Palefsky JM, Barrasso R. H PV infection and disease in men. In: Human Papillomavirus II. 0 bstet Gynecol Clin 1996;23:895-915.

37. Flores Y, Shah K, Lazcano E, Hernández M, Bishai D, Ferris D et al. D esign and methods of the evaluation of an HPV-based cervical cancer screening strategy in Mexico:The Morelos H PV Study. Salud Publica Mex 2002;44(4):335-344.

38. Lazcano EC, Herrero R, Muñoz N , Cruz A, Shah KV,Alonso P et al. Epidemiology of HPV infection among Mexican women with normal cytology. Int J Cancer 2001;91(3): 412-420.

39. Herrero R, Hildesheim A, Bratti C, Sherman M, Hutchinson M, Morales J et al. A population-based study of human papillomavirus infection and cervical neoplasia in rural C osta Rica. JN CI 2000;92(6): 464-474.

40. Lörincz A, Reid R, Jenson B, G reenberg M, Lancaster W, Kurman R. Human papillomavirus infection of the cervix: Relative risk associations of 15 common anogenital types. 0 bstet $G$ ynecol 1992;79:328-37. 41. C uzick J,Terry G, Ho L, Hollingworth T, Anderson M. Type-specific human papillomavirus DNA in abnormal smears as a predictor of highgrade cervical intraepithelial neoplasia. Br J Cancer 1994;69:167-171. 42. Remmink AJ, W alboomers JM, Helmerhorst TJ,Voorhorst FJ, Rozendaal L, Risse EK et al.The presence of persistent high-risk HPV genotypes in dysplastic cervical lesions is associated with progressive disease: $N$ atural history up to 36 months. Int I Cancer 1995;61:306-311. 43.W allin KL,W iklund F,Angstrom T, Bergman F, Stendahl U, W adell $G$, et al. Type-specific persistence of human papillomavirus DN A before the development of invasive cervical cancer. N Engl J Med 1999;341:16331638.

44. Zhang MZ, Borchardt KA, Li Z. Condyloma acuminatum. In: Borchardt KA, N obel MA, eds. Sexually Transmitted D iseases. N ew York: CRC Press, 1997:271-282.

45. Richart RM, Masood S, Syrjanen KJ,Vassilakos P, Kaufman RH, O Iszewski W T, et al. Human papillomavirus IAC task force summary. Acta Cytol 1998;42:50-58.

46. Sedlacek TV.Advances in the diagnosis and treatment of human papillomavirus infections. C lin 0 bstet Gynecol. 1999;42:206-220.

47. Strand A, Rylander E. Human papillomavirus. Subclinical and atypical manifestations. D ermatol C lin 1998;16: 817-822.

48. Moscicki AB, Shiboski S, Broering J, Powell K, Clayton L, Jay N et al. The natural history of human papillomavirus infection as measured by repeated DNA testing in adolescent and young women.J Pediatr 1998;132:277-284

49. Rome RM, Chanen W, Pagano R.The natural history of human papillomavirus (HPV) atypia of the cervix. Aust N Z J O bst Gynaecol $1987 ; 27: 287-290$
50.W orld Health 0 rganization. IARC Monograph on the Evaluation of Carcinogenic Risks to Humans: Human Papillomaviruses. Lyons: IARC, 1995; Vol. 64.

51. Brinton LA, Epidemiology of cervical cancer-overview. In: Muñoz $\mathrm{N}$, Bosch FX, Shah KV, Meheus A, eds. The Epidemiology of Cervical C ancer and Human Papillomavirus. Lyon: IARC, 1992.

52. Ho GY, Burk D D, Klein S, Kadish AS, C hang CJ, Palan P et al. Persistent genital human papillomavirus infection as a risk factor for persistent cervical dysplasia.J N atl C ancer Inst 1995;87:1365-1371. 53.Villa L. Human papillomaviruses and cervical cancer. Adv C ancer Res 1997;71:321-341.

54. Muñoz N , Bosch FX, De Sanjosé S, Shah KV.The role of HPV in the etiology of cervical cancer. Mutation Res 1994;305:293-301.

55. Lörincz A. Hybrid CaptureTM method for detection of human papillomavirus D N A in clinical specimens. Papillomavirus Rep 1996;7:1-5. 56. Salmerón J, Lazcano EC, Lörincz A, Hernández M, Hernández P, Leyva A et al. Comparison of HPV-based assays with Papanicolaou smears for cervical cancer screening in Morelos State, Mexico. Cancer Causes Control 2003;14:505-512.

57. Schiffman M, Herrero R, Hildesheim A, Sherman M, Bratti M, $W$ acholder $S$ et al. HPV DNA testing in cervical cancer screening: Results from women in a high-risk province of Costa Rica. JAMA 2000;283:87-93.

58.W omack SD, Chirenje ZM, Blumenthal PD, G affikin L, McG rath JA, Chipato $T$ et al. Evaluation of a human papillomavirus assay in cervical screening in Zimbabwe. BJO G 2000;107:33-8.

59.W right TC, D enny L, Kuhn L, Pollack A, Lörincz A. HPV D N A testing of self-collected vaginal samples compared with cytologic screening to detect cervical cancer. JAMA 2000;283:81-86.

60. Lin CT, Tseng CJ, Lai CH, H sueh S, Huang HJ, Law KS. High-risk HPV DNA detection by Hybrid Capture II. An adjunctive test for mildly abnormal cytologic smears in women $>$ or $=50$ years of age. Reprod Med 2000;45(4):345-350.

61. Sellors JW, Lörincz AT, Mahony JB, Mielzynska I, Lytwyn A, Roth P et al. Comparison of self-collected vaginal, vulvar and urine samples with physician-collected cervical samples for human papillomavirus testing to detect high-grade squamous intraepithelial lesions. CMAJ 2000;163:513518.

62. Fait G, Kupferminc MJ, D aniel Y, G eva E, Ron IG, Lessing JB et al. Contribution of human papillomavirus testing by hybrid capture in the triage of women with repeated abnormal pap smears before colposcopy referral. Gynecol 0 ncol 2000;79:177-180.

63. Bergeron C, Jeannel D, Poveda J, C assonnet P, O rth G. Human papillomavirus testing in women with mild cytologic atypia. 0 bstet Gynecol 2000;95:821-827.

64. Clavel C, Masure M, Bory JP, Putaud I, Mangeonjean C, Lorenzato M et al. Hybrid $C$ apture II-based human papillomavirus detection, a sensitive test to detect in routine high-grade cervical lesions: a preliminary study on 1518 women. Br J C ancer 1999:80:1306-1311. 65. Cuzick J, Beverley E, Ho L,Terry G, Sapper H, Mielzynska I et al. H PV testing in primary screening of older women. $\mathrm{Br}$ J Cancer 1999;8:554558.

66. Ferris DG,W right TC, Litaker MS, Richart RM, Lörincz AT, X aio-W ei $S$ et al. Comparison of two tests for detecting carcinogenic HPV in women with papanicolaou smear reports of ASC US and LSIL.J Fam Pract 1998;46:136-141.

67. Ratnam S, Franco EL, Ferenczy A. Human papillomavirus testing for primary screening of cervical cancer precursors. Cancer Epidem Biomar 2000:9:945-951.

68. 18th International Papillomavirus Conference. Charleston, SC, USA. January 9-15, 1999.

69. D zuba I,Yunes-Díaz E,Allen B, Flores Y, Lazcano-Ponce EC, Shah K et al.The acceptability of self-collected samples for HPV testing vs. the pap 
test as alternatives in cervical cancer screening.J Womens $\mathrm{H}$ ealth $\mathrm{G}$ end Based Med 2002;11(3):265-275.

70. C uzick J, Sasieni P, D avies P, A dams J, N ormand C, Frater A et al. A systematic review of the role of human papillomavirus testing within a cervical screening program. Health Technol Assess 1999;3(14):i-iv, 1-204.

71. van Ballegooijen $M$, van den A kker-van Marle $M E, W$ armerdam PG, Meijer CJ,W alboomers JM, H abbema JD. Present evidence on the value of HPV testing for cervical cancer screening: a modelbased exploration of the (cost-) effectiveness. $\mathrm{Br}$ J Cancer 1997;76:651-657.

72. Flores Y, Bishai d, Lörincz A, Lazcano E, Hernández M, Salmerón J, Shah K. Cost-effectiveness of HPV testing as compared to the Pap in Mexico. 20th International Papillomavirus Conference. Paris, France. 0 ctober 4-9, 2002. 